\title{
Risk factors for lung metastasis at presentation with malignant primary osseous neoplasms: a population-based study
}

\author{
Lin Xie ${ }^{\dagger}$, Weibo Huang ${ }^{\dagger}$, Hongli Wang, Chaojun Zheng and Jianyuan Jiang ${ }^{*}$
}

\begin{abstract}
Background: Large population-based studies of risk factor for lung metastases at the presentation with primary osseous neoplasms are lacking and necessary. We aim to examine potential risk factors of lung metastases at presentation with primary osseous neoplasms using Surveillance, Epidemiology, and End Results (SEER) database tool.

Methods: We collected patients diagnosed with primary osseous neoplasms between 2010 and 2015 from the SEER database. Patients were divided into two groups: patients with lung metastases or patients without lung metastases. Patient characteristics such as age, sex, race, tumor size, histologic types, histologic grade, and lung metastasis were collected. Univariate and multivariate logistic regression analyses were applied to determine which characteristics were risk factors for lung metastasis at diagnosis.

Results: A total of 4459 patients were collected, and 507 patients had lung metastases at presentation. Data on age, race, gender, primary site, grade, tumor size, and histology types were enrolled into the multivariate logistic analysis. Higher grade ( $\mathrm{OR}=5.197,95 \% \mathrm{Cl} 3.328$ to 8.117 ), histology type (Ewing sarcoma: $\mathrm{OR}=1.432,95 \% \mathrm{Cl} 1.020$ to 2.009; osteosarcoma: $\mathrm{OR}=1.597,95 \% \mathrm{Cl}, 1.073$ to 2.377 ), and larger tumor size ( $\geq 5 \mathrm{~cm}$ : $\mathrm{OR}=3.528,95 \% \mathrm{Cl} 2.370$ to 5.251) were associated with an increased risk of lung metastasis at presentation.

Conclusion: Histology types (osteosarcoma and Ewing sarcoma) were related to a higher risk of lung metastases in primary osseous neoplasms patients. Patients with osteosarcoma and lager tumors or higher tumor grade were associated with higher possibility of lung metastases. Patients with Ewing sarcoma and larger tumors have more tendency of lung metastases. These patients are supposed to receive chest $\mathrm{CT}$ scans at the presentation with primary osseous neoplasms.
\end{abstract}

Keywords: Osseous neoplasms, Risk factor, Lung metastasis

\section{Introduction}

Primary osseous neoplasms were rare diseases with high mortality and affected patients of every age. Metastases were factors for worse prognosis for these patients, which might be a cause of death of these patients. Primary osseous neoplasms have metastatic potential to the lung, liver, and brain, and the lung is the main target.

\footnotetext{
* Correspondence: 18111220066@fudan.edu.cn

${ }^{\dagger}$ Lin Xie and Weibo Huang contributed equally to this work.

Department of Orthopedics, Huashan Hospital, Fudan University, 12 Mid-Wulumuqi Road, Shanghai 200040, China
}

Although surgical amputation was often performed for patients with osteosarcoma before the advent of cancer chemotherapy, approximately $80 \%$ of patients still died of lung metastases $[1,2]$. Among these patients, most of them have no obvious symptoms over a long period of time. In fact, according to previous literature, approximately $10-40 \%$ of patients had lung metastases at the presence of primary osseous neoplasms [3, 4]. Patients with lung metastasis were generally diagnosed by lung CT scan following diagnosis of primary osseous neoplasms. And the current treatment for patients with lung

(c) The Author(s). 2020 Open Access This article is distributed under the terms of the Creative Commons Attribution 4.0 International License (http://creativecommons.org/licenses/by/4.0/), which permits unrestricted use, distribution, and 
metastasis is complete surgical resection [5]. However, to the best of our knowledge, analysis of risk factors for lung metastasis in patients with primary osseous neoplasm has not been reported.

We used the Surveillance, Epidemiology, and End Results (SEER) Program database, which is commonly used for the analysis of rare cancer. The SEER database represents approximately $30 \%$ of the US population. Previous studies reported some social and clinical factors may be risk factors of lung metastases at presentation with malignant primary osseous neoplasms, but more researches are needed to reveal the associations.

The purpose of the present study was to examine the potential risk factors related to an increased rate of lung metastases at presentation with primary osseous neoplasms. A better understanding of the risk and the clinicopathological features of primary osseous neoplasm patients with lung metastases can help identify patients with high-risk factors and improve prognosis.

\section{Materials and methods Patient cohort}

Patient information was accessed using the SEER database, which comprises 18 cancer registries and covers approximately $30 \%$ of the US population. The SEER database was accessed using SEER*Stat software (version 8.3.4).

The inclusion criteria were used as follows: (1) primary osseous neoplasms, (2) diagnosed between 2010 and 2015, (3) site limited to a bone only, and (4) diagnosis acquired in a living patient. The exclusion criteria were used as follows: unknown status of lung metastasis.

\section{Statistical analysis}

The incorporated variables were compared between groups with the presence or absence of metastasis using chi-squared test. Univariate logistic analysis was used to select variables as possible risk factors associated with distant metastasis. Multivariate logistic analysis was then applied to determine the risk factors selected in the univariate analysis.

Chi-squared test, univariate logistic analysis, and multivariate logistic analysis were conducted via SPSS version 24. A two-sided $p<0.05$ was considered statistically significant.

\section{Results}

\section{Patient baseline characteristics}

A total of 4459 primary osseous neoplasms patients diagnosed from 2010 to 2015 were collected from the SEER database. Patient characteristics are listed in Table 1. Of the 4459 patients with primary osseous neoplasms, 2530 (56.7\%) were female and 1929 (43.3\%) were male. A total of $1144(25.7 \%)$ patients were diagnosed with low grade, and 1606 (36.0\%) were diagnosed with high grade. Among these patients, 507 (11.4\%) patients had lung metastases. Based on the chi-squared test between non-metastatic and metastatic patients, an increased rate of lung metastasis was found to be associated with younger age, extremity site, higher grade, lager tumor size, osteosarcoma, and Ewing sarcoma (Table 1).

\section{Risk factors for metastasis to lung at diagnosis}

Data on age, race, gender, primary site, grade, and tumor size were enrolled into the univariate logistic regression analysis. Age, gender, primary site, grade, tumor size, and histology type were found to be associated with lung metastasis in the univariate analysis. After controlling for confounding variables using multivariate logistic analysis, gender, histology type, grade, and tumor size were identified as independent risk factors for lung metastasis at diagnosis, while age lost significance (Tables 2 and 3).

Specifically, multivariate analysis demonstrated an increased risk of metastasis among male patients: OR = 1.243, 95\% CI 1.020 to 1.516; patients with osteosarcoma: $\mathrm{OR}=1.432,95 \%$ CI 1.020 to 2.009 ; patients with Ewing sarcoma: $\mathrm{OR}=1.597,95 \% \mathrm{CI} 1.073$ to 2.377 ; patients with higher grade: $\mathrm{OR}=5.197,95 \%$ CI 3.328 to 8.117; and patients with a tumor larger than $5 \mathrm{~cm}$ : $\mathrm{OR}=$ $3.528,95 \%$ CI 2.370 to 5.251 .

\section{Risk factors for metastasis to lung at diagnosis of osteosarcoma}

Data on age, race, gender, primary site, grade, and tumor size were enrolled into the univariate logistic regression analysis. Gender, grade, and tumor size were found to be associated with lung metastasis in the univariate analysis. After controlling for confounding variables using multivariate logistic analysis, grade and tumor size were identified as independent risk factors for lung metastasis at diagnosis, while gender lost significance. Specifically, multivariate analysis demonstrated an increased risk of metastasis among higher grade patients: $\mathrm{OR}=4.861,95 \%$ CI 1.948 to 12.131; and patients with lager tumor: OR = 3.432, 95\% CI 1.715 to 6.867 (Table 4).

\section{Risk factors for metastasis to the lung at diagnosis of Ewing sarcoma}

Data on age, race, gender, primary site, grade, and tumor size were enrolled into the univariate logistic regression analysis. Tumor size was found to be associated with lung metastasis in the univariate analysis. After controlling for confounding variables using multivariate logistic analysis, tumor size was identified as an independent risk factor (OR $=5.213,95 \%$ CI 2.052 to 13.245) for lung metastasis at diagnosis (Table 5). 
Table 1 Characteristics of patients with malignant primary osseous neoplasms by lung metastasis

\begin{tabular}{|c|c|c|c|c|}
\hline Characteristic & $\begin{array}{l}\text { Total, } N=4459 \\
\text { No. (\%) }\end{array}$ & $\begin{array}{l}\text { Non-metastatic to lung, } N=3952 \\
\text { No. (\%) }\end{array}$ & $\begin{array}{l}\text { Metastatic to lung, } N=507 \\
\text { No. }(\%)\end{array}$ & $P$ \\
\hline Age & & & & $<0.001$ \\
\hline$<30$ & $1810(40.6)$ & 1521 (38.5) & 289 (57.0) & \\
\hline$\geq 30$ & 2649 (59.4) & $2431(61.5)$ & $218(43.0)$ & \\
\hline Race & & & & 0.312 \\
\hline White & 3667 (82.2) & $3258(82.4)$ & $409(80.7)$ & \\
\hline Black & $412(9.2)$ & $354(9.0)$ & $58(11.4)$ & \\
\hline Other $^{1}$ & $348(7.8)$ & $312(7.9)$ & $36(7.1)$ & \\
\hline Unknown & $32(0.7)$ & $28(0.7)$ & $4(0.8)$ & \\
\hline Gender & & & & 0.005 \\
\hline Male & $2530(56.7)$ & $2213(56.0)$ & $317(62.5)$ & \\
\hline Female & 1929 (43.3) & $1739(44.0)$ & $190(37.5)$ & \\
\hline Primary site & & & & $<0.001$ \\
\hline Extremity & $2273(51.0)$ & 1973 (49.9) & $300(59.2)$ & \\
\hline Axial & $2186(49.0)$ & 1979 (50.1) & 207 (40.8) & \\
\hline Grade & & & & $<0.001$ \\
\hline Low grade & $1144(25.7)$ & 1117 (28.3) & $27(5.3)$ & \\
\hline High grade & 1606 (36.0) & $1343(34.0)$ & $263(51.9)$ & \\
\hline Unknown & 1709 (38.3) & $1492(37.8)$ & $217(42.8)$ & \\
\hline Tumor size & & & & $<0.001$ \\
\hline$<5$ & $1029(23.1)$ & $1000(25.3)$ & $29(5.7)$ & \\
\hline$\geq 5$ & 2667 (59.8) & 2309 (58.4) & 358 (70.6) & \\
\hline Unknown & $763(17.1)$ & $643(16.3)$ & $120(23.7)$ & \\
\hline Histology type & & & & $<0.001$ \\
\hline Osteosarcoma & $1457(32.7)$ & $1225(31.0)$ & $232(45.8)$ & \\
\hline Ewing sarcoma & $592(13.3)$ & $481(12.2)$ & $111(21.9)$ & \\
\hline Chondrosarcoma & $1292(29.0)$ & $1223(30.9)$ & 69 (13.6) & \\
\hline Squamous cell carcinoma & $72(1.6)$ & $68(1.7)$ & $4(0.8)$ & \\
\hline Spindle cell sarcoma & $54(1.2)$ & $45(1.1)$ & $9(1.8)$ & \\
\hline Chordoma & $461(10.3)$ & $456(11.5)$ & $5(1.0)$ & \\
\hline Giant cell sarcoma & $112(2.5)$ & $98(2.5)$ & $14(2.8)$ & \\
\hline Small cell sarcoma & $5(0.1)$ & $3(0.1)$ & $2(0.4)$ & \\
\hline Epithelioid sarcoma & $23(0.5)$ & $19(0.4)$ & $4(0.8)$ & \\
\hline Small round cell tumor & $5(0.1)$ & $3(0.1)$ & $2(0.4)$ & \\
\hline Fibrosarcoma & $62(1.4)$ & $54(1.4)$ & $8(1.6)$ & \\
\hline Adamantinoma & $17(0.4)$ & $17(0.4)$ & $0(0)$ & \\
\hline Hemangiosarcoma & $50(1.1)$ & $46(1.2)$ & $4(0.8)$ & \\
\hline Synovial sarcoma & $16(0.4)$ & $12(0.3)$ & $4(0.8)$ & \\
\hline Leiomyosarcoma & $25(5.6)$ & $24(0.9)$ & $1(0.2)$ & \\
\hline Other & $216(4.8)$ & $178(4.5)$ & $38(7.5)$ & \\
\hline
\end{tabular}

SEER 2010-2015

${ }^{1}$ Including American Indian/Alaska Native, Asian/Pacific Islander 
Table 2 Univariate and multivariate logistic regression analysis for patients with malignant primary osseous neoplasms by lung metastasis

\begin{tabular}{|c|c|c|c|c|}
\hline \multirow[t]{2}{*}{ Characteristic } & \multicolumn{2}{|l|}{ Univariate analysis } & \multicolumn{2}{|l|}{ Multivariate analysis } \\
\hline & OR $(95 \% \mathrm{Cl})$ & P & $\mathrm{OR}(95 \% \mathrm{Cl})$ & $P$ \\
\hline \multicolumn{5}{|l|}{ Age } \\
\hline$<30$ & Reference & & Reference & \\
\hline$\geq 30$ & $0.472(0.391-0.569)$ & $<0.001$ & $0.902(0.713-1.141)$ & 0.391 \\
\hline \multicolumn{5}{|l|}{ Race } \\
\hline White & Reference & & $\mathrm{Nl}$ & \\
\hline Black & $1.305(0.971-1.755)$ & 0.078 & & \\
\hline Other $^{1}$ & $0.919(0.641-1.317)$ & 0.646 & & \\
\hline Unknown & $1.138(0.397-3.261)$ & 0.810 & & \\
\hline \multicolumn{5}{|l|}{ Gender } \\
\hline Male & Reference & & Reference & \\
\hline Female & $1.311(1.084-1.586)$ & 0.005 & $1.243(1.020-1.516)$ & 0.031 \\
\hline \multicolumn{5}{|l|}{ Primary site } \\
\hline Extremity & Reference & & Reference & \\
\hline Axial & $0.688(0.570-0.830)$ & $<0.001$ & $1.065(0.860-1.319)$ & 0.563 \\
\hline \multicolumn{5}{|l|}{ Grade } \\
\hline Low grade & Reference & & Reference & \\
\hline High grade & $5.346(3.636-7.862)$ & $<0.001$ & $5.197(3.328-8.117)$ & $<0.001$ \\
\hline Unknown & 6.435 (4.239-9.770) & $<0.001$ & $5.106(3.223-8.088)$ & $<0.001$ \\
\hline \multicolumn{5}{|l|}{ Tumor size } \\
\hline$<5$ & Reference & & Reference & \\
\hline$\geq 5$ & 8.102 (5.409-12.134) & $<0.001$ & $3.528(2.370-5.251)$ & $<0.001$ \\
\hline Unknown & 6.017 (4.003-9.043) & $<0.001$ & $4.346(2.831-6.673)$ & $<0.001$ \\
\hline \multicolumn{5}{|l|}{ Histology type } \\
\hline Osteosarcoma & Reference & & $1.432(1.020-2.009)$ & 0.038 \\
\hline Ewing sarcoma & $1.219(0.949-1.564)$ & 0.121 & $1.597(1.073-2.377)$ & 0.021 \\
\hline Chondrosarcoma & $0.298(0.225-0.394)$ & $<0.001$ & Reference & \\
\hline Squamous cell carcinoma & $0.311(0.112-0.860)$ & 0.024 & $1.233(0.420-3.620)$ & 0.704 \\
\hline Spindle cell sarcoma & $1.054(0.509-2.190)$ & 0.884 & $1.749(0.797-3.841)$ & 0.163 \\
\hline Chordoma & $0.058(0.024-0.141)$ & $<0.001$ & $0.102(0.04-0.261)$ & $<0.001$ \\
\hline Giant cell sarcoma & $0.754(0.423-1.344)$ & 0.338 & $1.027(0.545-1.934)$ & 0.934 \\
\hline Small cell sarcoma & $3.520(0.585-21.183)$ & 0.169 & $4.677(0.700-31.234)$ & 0.111 \\
\hline Epithelioid sarcoma & $1.112(0.375-3.297)$ & 0.849 & $1.807(0.576-5.668)$ & 0.310 \\
\hline Small round cell tumor & $3.520(0.585-21.183)$ & 0.169 & $5.216(0.761-35.758)$ & 0.093 \\
\hline Fibrosarcoma & $0.782(0.367-1.665)$ & 0.524 & $1.505(0.672-3.309)$ & 0.321 \\
\hline Adamantinoma & NA & 0.998 & NA & 0.998 \\
\hline Hemangiosarcoma & $0.459(0.164-1.288)$ & 0.139 & $0.775(0.263-2.287)$ & 0.645 \\
\hline Synovial sarcoma & $1.760(0.563-5.505)$ & 0.331 & $2.858(0.852-9.591)$ & 0.089 \\
\hline Leiomyosarcoma & $0.220(0.030-1.634)$ & 0.139 & $0.386(0.05-2.946)$ & 0.358 \\
\hline Other & $1.127(0.773-1.644)$ & 0.534 & $1.572(0.992-2.493)$ & 0.054 \\
\hline
\end{tabular}


Table 3 Number (\%) of patients with lung metastases according to histology type, tumor size, tumor grade, and gender

\begin{tabular}{ll}
\hline Characteristic & Number (\%) of patients with lung metastases \\
\hline Histology type & \\
Ewing sarcoma & $111(18.8)$ \\
Osteosarcoma & $232(15.9)$ \\
Chondrosarcoma & $69(5.3)$ \\
Chordoma & $5(1.1)$ \\
Tumor size & \\
$<5$ cm & $29(2.8)$ \\
$\geq 5 \mathrm{~cm}$ & $358(13.4)$ \\
Grade & $27(2.4)$ \\
Low & $263(16.4)$ \\
High &
\end{tabular}

Risk factors for metastasis to the lung at diagnosis of chondrosarcoma

Data on age, race, gender, primary site, grade, and tumor size were enrolled into the univariate logistic regression analysis. Gender, grade, and tumor size were found to be associated with lung metastasis in the univariate analysis. After controlling for confounding variables using multivariate logistic analysis, tumor grade was identified as an independent risk factor $(\mathrm{OR}=6.204,95 \%$ CI 3.483 to 11.048) for lung metastasis at diagnosis (Table 6), while gender and tumor size lost significance.

\section{Discussion}

Lung metastases are of particular poor prognosis among patients with primary osseous neoplasms. It is assumed that approximately $10-40 \%$ of the patients have detectable lung metastases at diagnosis of malignant primary osseous neoplasms. In our study, analysis of the SEER database from 2010 to 2015 revealed that $11.4 \%$ cases of primary osseous neoplasms presented with lung metastases at the time of initial diagnosis. Osteosarcoma, Ewing sarcoma, larger tumors, and higher grade were

Table 4 Univariate and multivariate logistic regression analysis for patients with osteosarcoma by lung metastasis

\begin{tabular}{|c|c|c|c|c|}
\hline \multirow[t]{2}{*}{ Characteristic } & \multicolumn{2}{|l|}{ Univariate analysis } & \multicolumn{2}{|l|}{ Multivariate analysis } \\
\hline & OR $(95 \% \mathrm{Cl})$ & $P$ & OR $(95 \% \mathrm{Cl})$ & $P$ \\
\hline \multicolumn{5}{|l|}{ Age } \\
\hline$<30$ & Reference & & $\mathrm{Nl}$ & \\
\hline$\geq 30$ & $0.821(0.608-1.108)$ & 0.197 & & \\
\hline \multicolumn{5}{|l|}{ Race } \\
\hline White & Reference & & $\mathrm{Nl}$ & \\
\hline Black & $1.142(0.779-1.673)$ & 0.497 & & \\
\hline Other $^{1}$ & $1.043(0.636-1.711)$ & 0.867 & & \\
\hline Unknown & $1.083(0.126-9.328)$ & 0.942 & & \\
\hline \multicolumn{5}{|l|}{ Gender } \\
\hline Male & Reference & & Reference & \\
\hline Female & $1.410(1.057-1.881)$ & 0.019 & $1.267(0.945-1.698)$ & 0.114 \\
\hline \multicolumn{5}{|l|}{ Primary site } \\
\hline Extremity & Reference & & & \\
\hline Axial & $0.862(0.623-1.192)$ & 0.368 & $\mathrm{Nl}$ & \\
\hline \multicolumn{5}{|l|}{ Grade } \\
\hline Low grade & Reference & & Reference & \\
\hline High grade & $5.769(2.328-14.296)$ & 0.000 & $4.861(1.948-12.131)$ & 0.001 \\
\hline Unknown & $5.381(2.106-13.751)$ & 0.000 & $4.326(1.681-11.136)$ & 0.002 \\
\hline \multicolumn{5}{|l|}{ Tumor size } \\
\hline$<5$ & Reference & & Reference & \\
\hline$\geq 5$ & $4.107(2.064-8.171)$ & 0.000 & $3.432(1.715-6.867)$ & $<0.001$ \\
\hline Unknown & 6.281 (2.969-13.288) & 0.000 & $5.470(2.568-11.654)$ & $<0.001$ \\
\hline
\end{tabular}


Table 5 Univariate and multivariate logistic regression analysis for patients with Ewing sarcoma by lung metastasis

\begin{tabular}{|c|c|c|c|c|}
\hline \multirow[t]{2}{*}{ Characteristic } & \multicolumn{2}{|l|}{ Univariate analysis } & \multicolumn{2}{|l|}{ Multivariate analysis } \\
\hline & OR $(95 \% \mathrm{Cl})$ & $P$ & OR $(95 \% \mathrm{Cl})$ & $P$ \\
\hline \multicolumn{5}{|l|}{ Age } \\
\hline$<30$ & Reference & & $\mathrm{NI}$ & \\
\hline$\geq 30$ & $0.942(0.539-1.645)$ & 0.833 & & \\
\hline \multicolumn{5}{|l|}{ Race } \\
\hline White & Reference & & $\mathrm{NI}$ & \\
\hline Black & $1.509(0.589-3.927)$ & 0.399 & & \\
\hline Other $^{1}$ & $0.497(0.192-0.288)$ & 0.150 & & \\
\hline Unknown & $4.276(0.595-30.728)$ & 0.149 & & \\
\hline \multicolumn{5}{|l|}{ Gender } \\
\hline Male & Reference & & & \\
\hline Female & $1.205(0.787-1.845)$ & 0.391 & $\mathrm{NI}$ & \\
\hline \multicolumn{5}{|l|}{ Primary site } \\
\hline Extremity & Reference & & & \\
\hline Axial & $1.232(0.811-1.871)$ & 0.329 & $\mathrm{NI}$ & \\
\hline \multicolumn{5}{|l|}{ Grade } \\
\hline Low grade & Reference & & & \\
\hline High grade & NA & 0.999 & $\mathrm{Nl}$ & \\
\hline Unknown & NA & 0.999 & & \\
\hline \multicolumn{5}{|l|}{ Tumor size } \\
\hline$<5$ & Reference & & Reference & \\
\hline$\geq 5$ & $5.213(2.052-13.245)$ & 0.001 & $5.213(2.052-13.245)$ & 0.001 \\
\hline Unknown & $5.820(2.149-15.764)$ & 0.001 & $5.820(2.149-15.764)$ & 0.001 \\
\hline
\end{tabular}

associated with a higher risk of lung metastases in primary osseous neoplasm patients at diagnosis.

Primary osseous neoplasms are rare malignancies in the bone. Some of the more common malignant tumors include osteosarcoma, Ewing sarcoma, chondrosarcoma, and chordoma [6, 7]. Lung metastasis was the poor survival factor in these patients $[8,9]$. Death from malignant bone tumors is usually the result of progressive lung metastasis with respiratory failure secondary to widespread disease $[10,11]$. We found that the incidence of lung metastasis was 18.8\% (Ewing sarcoma), 15.9\% (osteosarcoma), 5.3\% (chondrosarcoma), and 1.1\% (chordoma). Ewing sarcoma is highly malignant with early metastasis to the lung and bone. Metastasis is commonly hematogenous and related to stemness [12]. Osteosarcoma is the most common primary malignant bone sarcoma and affects all ages. Previous studies report that $10-47 \%$ of osteosarcoma patients have lung metastasis at diagnosis [13]. Bielack et al. found that the incidence proportion of lung metastasis was $10.75 \%$ [14]. Kaste et al. reported that the incidence of lung metastases among patients with osteosarcoma was 15\% [13]. Munajat et al. found that 33 patients (47\%) had evidence of lung metastasis in a cohort of 70 patients with osteosarcoma [15]. Huang et al. found that the incidence of lung metastasis was $16.7 \%$ of patients with osteosarcoma [16]. In our study, we found osteosarcoma patients with larger tumor size or higher malignancy are risk factors for lung metastases. Chondrosarcoma is the second most frequent primary malignant bone sarcoma [17]. However, it is considered that metastasis is less common in patients with chondrosarcoma [17-19], while patients with chondrosarcoma and higher grade have more chance of lung metastases. Previous study reported that $11.2 \%$ of patients at 11 hospitals developed lung metastases after initial treatment of primary chondrosarcoma [20]. In our study, 5.3\% (chondrosarcoma) has lung metastases. The rate of metastasis is related to histological tumor grade. Although Ewing sarcoma was a rare sarcoma type in younger age, in our study, Ewing sarcoma is the most common lung metastases sarcoma type. The rate of lung metastases is $18.8 \%$. Patients with Ewing sarcoma and larger tumors have more chance of lung metastases.

Through the SEER database, we used large sample analysis to observe the risk factors of lung metastasis in malignant bone tumors. We determined that larger tumor size is an independent risk factor for lung metastasis at presentation. The larger the tumor size, the more lung metastases at diagnosis. Tumor size has been previously reported to be an independent prognostic factor for overall survival of patients with osteosarcoma and the occurrence of lung metastasis on plain radiographs or magnetic resonance imaging (MRI) [10]. Munajat et al. reported that larger tumors are more likely to correlate with lung metastasis in their cohort of 70 patients with osteosarcoma [15]. Changes in tumor size may be closely related to its biological behavior [21]. A large primary tumor is more likely to be associated with distant metastasis.

We also identified higher tumor grade as an independent risk factor for lung metastasis at diagnosis. Previous studies reported that $40-60 \%$ of patients of the highgrade sarcomas will develop lung metastases, of which $70-80 \%$ will have disease limited to lungs, likely through hematogenous spread [21]. Bjornsson et al. revealed that high grade (II or III) was significantly related to both increased risks of recurrence $(36.2 \%$ of recurrence at 10 years vs. $15.2 \%$ for grade I; $p<0.001)$ and metastasis (29.3\% of metastasis at 5 years vs. $4.6 \%$ for grade I; $p<$ 0.001 ) [20]. Giuffrida et al. found that high-grade tumors had a hazard ratio of 3.4 for death when compared with low-grade tumors [22]. Song et al. found that higher grade was associated with an increased risk of metastasis at presentation, which demonstrated the high tendency to metastasize in high-grade tumors [23]. 
Table 6 Univariate and multivariate logistic regression analysis for patients with chondrosarcoma by lung metastasis

\begin{tabular}{|c|c|c|c|c|}
\hline \multirow[t]{2}{*}{ Characteristic } & \multicolumn{2}{|l|}{ Univariate analysis } & \multicolumn{2}{|l|}{ Multivariate analysis } \\
\hline & OR $(95 \% \mathrm{Cl})$ & P & OR $(95 \% \mathrm{Cl})$ & $P$ \\
\hline \multicolumn{5}{|l|}{ Age } \\
\hline$<30$ & Reference & & $\mathrm{Nl}$ & \\
\hline$\geq 30$ & $3.216(0.999-10.355)$ & 0.05 & & \\
\hline \multicolumn{5}{|l|}{ Race } \\
\hline White & Reference & & $\mathrm{Nl}$ & \\
\hline Black & $1.038(0.406-2.654)$ & 0.938 & & \\
\hline Other $^{1}$ & $0.790(0.242-2.586)$ & 0.790 & & \\
\hline Unknown & $1.471(0.188-11.500)$ & 0.713 & & \\
\hline \multicolumn{5}{|l|}{ Gender } \\
\hline Male & Reference & & Reference & \\
\hline Female & $1.683(1.002-2.828)$ & 0.049 & $1.502(0.881-2.559)$ & 0.135 \\
\hline \multicolumn{5}{|l|}{ Primary site } \\
\hline Extremity & Reference & & $\mathrm{Nl}$ & \\
\hline Axial & 1.095 (0.674-1.782) & 0.713 & & \\
\hline \multicolumn{5}{|l|}{ Grade } \\
\hline Low grade & Reference & & Reference & \\
\hline High grade & $7.082(4.018-12.484)$ & 0.000 & $6.204(3.483-11.048)$ & $<0.001$ \\
\hline Unknown & 3.277 (1.599-6.718) & 0.001 & $3.137(1.520-6.473)$ & 0.002 \\
\hline \multicolumn{5}{|l|}{ Tumor size } \\
\hline$<5$ & Reference & & Reference & \\
\hline$\geq 5$ & $2.992(1.452-6.166)$ & 0.003 & $2.038(0.966-4.299)$ & 0.062 \\
\hline Unknown & 2.889 (1.195-6.984) & 0.018 & $2.322(0.944-5.711)$ & 0.066 \\
\hline
\end{tabular}

$O R$ odds ratio, $\mathrm{Cl}$ confidence interval, $N /$ not included. $n=1292$

${ }^{1}$ Including American Indian/Alaska Native, Asian/Pacific Islander

Several limitations should be taken into consideration in the present study. First, we did not include other potential risk factors such as pathologic fracture, which has proven to be a prognostic factor for survival. The reason was that the SEER database did not record these variables. In addition, specific location of the tumors or complete information regarding the size was not available in the SEER database. Finally, our results were analyzed based on retrospective cohort data; thus, prospective researches are needed for further validation.

\section{Conclusions}

The present study identified risk factors for lung metastases in patients with primary osseous neoplasms. It would be helpful for clinicians to evaluate patients' risk of lung metastasis and counsel patients regarding the possibility of lung metastasis at diagnosis. Moreover, our study could provide insights into clinicopathological factors which are related to the development of lung metastatic primary osseous neoplasms to diagnosis.

\section{Abbreviations}

Cl: Confidence interval; MRI: Magnetic resonance imaging; NI: Not included; OR: Odds ratio; SEER: Surveillance, Epidemiology, and End Results

\section{Acknowledgements}

Not applicable.

Authors' contributions

$L X, W B H$, and $J Y J$ designed the study. $L X$ and HLW collected the data. $L X$, $\mathrm{CJZ}$, and $J \mathrm{YJ}$ were involved in the manuscript writing, literature search, data interpretation, and data monitoring. LX was responsible for the data collection and analysis. All authors read and approved the final manuscript.

\section{Funding}

This work was supported by grants from the National Natural Science Foundation of China (no. 81802145, 81772388, 81972109).

\section{Availability of data and materials}

The patients' data were collected from SEER database.

Ethics approval and consent to participate

Not required.

Consent for publication

Not required.

Competing interests

The authors declare that they have no competing interest. 
Received: 17 July 2019 Accepted: 23 January 2020

Published online: 29 January 2020

\section{References}

1. Saumet L, Deschamps F, Marec-Berard P, et al. Radiofrequency ablation of metastases from osteosarcoma in patients under 25 years: the SCFE experience. Pediatr Hematol Oncol. 2015;32:41-9.

2. Rejniak KA, Lloyd MC, Reed DR, Bui MM. Diagnostic assessment of osteosarcoma chemoresistance based on virtual clinical trials. Med Hypotheses. 2015;85:348-54.

3. Pochanugool L, Subhadharaphandou T, Dhanachai M, Hathirat P, Sangthawan D, Pirabul R, Onsanit S, Pornpipatpong N. Prognostic factors among 130 patients with osteosarcoma. Clin Orthop Relat Res. 1997;345: 206-14.

4. Bieling $P$, Rehan N, Winkler P, Helmke $K$, Maas $R$, Fuchs N, Bielack S, Heise U, Jurgens $\mathrm{H}$, Treuner J, Romanowski R, Exner U, Kotz R, Winkler K. Tumor size and prognosis in aggressively treated osteosarcoma. J Clin Oncol. 1996;3: 848-58.

5. Nataraj V, Rastogi S, Khan SA, Sharma MC, Agarwala S, Vishnubhatla S, et al. Prognosticating metastatic osteosarcoma treated with uniform chemotherapy protocol without high dose methotrexate and delayed metastasectomy: a single center experience of 102 patients. Clin Transl Oncol. 2016;18:937-44.

6. Goorin AM, Abelson HT, Frei E 3rd. Osteosarcoma: fifteen years later. N Engl J Med. 1985;26:1637-43.

7. Meyers PA, Gorlick R. Osteosarcoma. Pediatr Clin N Am. 1997:4:973-89.

8. Brostrom LA, Strander H, Nilsonne U. Survival in osteosarcoma in relation to tumor size and location. Clin Orthop Relat Res. 1982;167:250-4.

9. Li W, Zhang S. Survival of patients with primary osteosarcoma and lung metastases. J BUON. 2018;5:1500-4.

10. Meyers PA, Heller G, Healey JH, Huvos A, Applewhite A, Sun M, LaQuaglia M. Osteogenic sarcoma with clinically detectable metastasis at initial presentation. J Clin Oncol. 1993;3:449-53.

11. Salah S, Toubasi S. Factors predicting survival following complete surgical remission of pulmonary metastasis in osteosarcoma. Mol Clin Oncol. 2015;1: 157-62.

12. Cotterill SJ, Ahrens S, Paulussen M, Jürgens HF, Voûte PA, Gadner H, Craft AW. Prognostic factors in Ewing's tumor of bone: analysis of 975 patients from the European Intergroup Cooperative Ewing's Sarcoma Study Group. J Clin Oncol. 2000;17:3108-14.

13. Kaste SC, Pratt CB, Cain AM, Jones-Wallace DJ, Rao BN. Metastases detected at the time of diagnosis of primary pediatric extremity osteosarcoma at diagnosis: imaging features. Cancer. 1999;8:1602-8.

14. Bielack SS, Kempf-Bielack B, Delling G, Exner GU, Flege S, Helmke K, Kotz R, Salzer-Kuntschik M, Werner M, Winkelmann W, Zoubek A, Jurgens H, Winkler K. Prognostic factors in high-grade osteosarcoma of the extremities or trunk: an analysis of 1,702 patients treated on neoadjuvant cooperative osteosarcoma study group protocols. J Clin Oncol. 2002;3:776-90.

15. Munajat I, Zulmi W, Norazman MZ, Wan Faisham WI. Tumour volume and lung metastasis in patients with osteosarcoma. J Orthop Surg (Hong Kong). 2008;2:182-5.

16. Huang X, Zhao J, Bai J, Shen H, Zhang B, Deng L, Sun C, Liu Y, Zhang J, Zheng J. Risk and clinicopathological features of osteosarcoma metastasis to the lung: a population-based study. J Bone Oncol. 2019;16:100230.

17. Lee FY, Mankin HJ, Fondren G, Gebhardt MC, Springfield DS, Rosenberg AE, et al. Chondrosarcoma of bone: an assessment of outcome. J Bone Joint Surg Am. 1999;81:326-38.

18. Gitelis S, Bertoni F, Picci P, Campanacci M. Chondrosarcoma of bone. The experience at the Istituto Ortopedico Rizzoli. J Bone Joint Surg Am. 1981;63: 1248-57.

19. Andreou D, Ruppin S, Fehlberg S, Pink D, Werner M, Tunn PU. Survival and prognostic factors in chondrosarcoma: results in 115 patients with longterm follow-up. Acta Orthop. 2011;82:749-55.

20. Nakamura T, Matsumine A, Yamada S, Tsukushi S, Kawanami K, Ohno T, et al. Oncological outcome after lung metastasis in patients presenting with localized chondrosarcoma at extremities: Tokai Musculoskeletal Oncology Consortium study. Onco Targets Ther. 2016;9:4747-51.

21. Briccoli A, Rocca M, Salone M, Guzzardella GA, Balladelli A, Bacci G. High grade osteosarcoma of the extremities metastatic to the lung: long-term results in 323 patients treated combining surgery and chemotherapy, 19852005. Surg Oncol. 2010;4:193-9.
22. Giuffrida AY, Burgueno JE, Koniaris LG, Gutierrez JC, Duncan R, Scully SP. Chondrosarcoma in the United States (1973 to 2003): an analysis of 2890 cases from the SEER database. J Bone Joint Surg Am. 2009;5:1063-72.

23. Song K, Shi X, Liang X, Wang H, Zou F, Lu F, Ma X, Jiang J. Risk factors for metastasis at presentation with conventional chondrosarcoma: a population-based study. Int Orthop. 2018;12:2941-8.

\section{Publisher's Note}

Springer Nature remains neutral with regard to jurisdictional claims in published maps and institutional affiliations.
Ready to submit your research? Choose BMC and benefit from:

- fast, convenient online submission

- thorough peer review by experienced researchers in your field

- rapid publication on acceptance

- support for research data, including large and complex data types

- gold Open Access which fosters wider collaboration and increased citations

- maximum visibility for your research: over $100 \mathrm{M}$ website views per year

At BMC, research is always in progress.

Learn more biomedcentral.com/submissions 